\title{
Tenggar Cave, Tulungagung: preliminary study and its paleontological potentials
}

\author{
Agus Tri Hascaryo ${ }^{1}$, Rusyad Adi Suriyanto ${ }^{2}$, Delta Bayu Murti ${ }^{3}$, and Tuti Koesbardiati ${ }^{3}$ \\ ${ }^{1}$ Doctoral alumni of Earth Science, Intitut Teknologi Bandung, Bandung, Indonesia \\ ${ }^{2}$ Laboratory of Bioanthropology and Paleoanthropology, Fakultas Kedokteran, Kesehatan \\ Masyarakat dan Keperawatan, Universitas Gadjah Mada, Yogyakarta, Indonesia \\ ${ }^{3}$ Department of Anthropology, Universitas Airlangga, Surabaya, Indonesia
}

\section{ABSTRACT}

Goa Tenggar or Tenggar Cave is situated in the karstic physiography of southern Tulungagung, East Java that made up of prehistoric caves. These include the Wajak complex (minimum age of 37.4 to 28.5 thousand years ago) and the Song Gentong (around $7000 \mathrm{BP}$ ). The formation of Tenggar Cave is influenced by the subterranean river that penetrates the limestone unit. This cave has a front width of $\pm 10 \mathrm{~m}$ and a roof height of $\pm 8 \mathrm{~m}$. The east side of the cave floor is a layer of soil, and the western side is the river. The inside of the cave composed by very compact conglomerate deposits and paleosoil that contains faunal remains, including Cervus sp., Bos sp., Bubalus sp., and Bibos sp., which may have occurred during the Pleistocene. The fossilized faunal remains from Tenggar Cave show that there was a relatively open environment during that time, such as a savannah with large trees and flowing rivers around the cave. The paleoenvironment indicates late Pleistocene to early Holocene period, similar to paleoenvironment in the Sewu Mountains that stretch along the southern part Java from central to the eastern tip of the island includes the coastal towns of Gunung Kidul, Pacitan and Tulungagung.

Copyright (C2021. FOSI. All rights reserved.

A Special Publication of abstracts and extended abstracts from the conference in honor of the retirement of Prof. Yahdi Zaim, IPU (22-23 March 2021).

DOI: $10.51835 /$ bsed.2021.47.3.353 
The situation is certainly a point of interest when associating the findings with the surrounding sites, starting from Wajak, Song Gentong, Pacitan, Ponorogo, and Gunung Kidul. However, absolute dating test is necessary to be more certain of the lifetime of the fossilized fauna. If the fossils were from the Late Pleistocene, it could be an important information for the fields of paleontology, paleoanthropology, and prehistoric archaeology given that the occurrence of sites with such antiquity are limited in Southeast Asia. It is essential to conduct intensive research in Tenggar Cave in the future.

Keywords: Tulungagung, Tenggar Cave, faunal remains fossil, Pleistocene, Holocene. 